\title{
Amylases and its Isozymes in the Yolk of Egg and in the Pancreas and the Serum of Domestic Fowl
}

\author{
Takeyuki Ikeno and Katsumi Niwa ${ }^{1)}$ \\ Ichinomiya Women's Junior College, Ichinomiya-shi 491 \\ 1) Ohu University School of Dentistry, Koriyama-shi 963
}

\begin{abstract}
We found amylase in the yolk of the ovary of a hen. Amylase was made in layers on the yolk and the total amount was in direct proportion to the weight of the yolk. The isoamylase pattern in the yolk of a fertilized egg was identical electrophoretically to that in the pancreas of the chick embryo during the incubation period. Polymorphism of isoamylases was seen in the yolk, the pancreas and the serum of a hen. The phenotype of isoamylases in these organs was one of three types (A, B or AB).
\end{abstract}

(Jpn. Poult. Sci., 32: 267-273, 1995)

Key words : amylase, isozyme, development, egg, hen

\section{Introduction}

We previously reported a marked increas in the amount of amylase activtiy in the yolk of fertilized eggs corresponding to development of the embryo (IKENO et al., 1991). A mechanism used to increase the amount of amylase activity in the yolk during incubation is partial accumulation of pancreatic amylase biosynthesized by the chick embryo. The source organ responsible for an increase of the amount of amylase in the yolk is the pancreas of the embryo (IKENo et al., 1992). Amylase activity was found not only in the fertilized egg but also in the unfertilized egg. We, therefore, think that there are two types of amylases in the yolk. One is the amylase in the yolk of an unfertilized egg or in a fertilized egg incubated for less than two weeks. This amylase may be synthesized at the same time yolks are formed in the ovary. Another type is detected in the yolk of a fertilized egg incubated for more than two weeks. This amylase is identical to pancreatic amylase in a chick embryo electrophoretically.

Some papers reported that there is polymorphism in saliva, serum and pancreatic amylases of animals (HASHIGUCHI et al., 1970 ; IкEMOTO et al., 1985 ; MATUSHIMA et al.,1990; SEARCY et al.,1966 ; MORAN,1982). In the previous report, authors et al. (1992) described the electrophoretic variations of amylase in the yolk and the pancreas. It is therefore necessary to analyze variations of amylase isozymes in the yolks of fertilized eggs, and relationships of amylases in the yolk of the ovary, the pancreas and the serum of a hen also should be examined.

In this paper, we describe contents of amylase in the yolk of the ovary and relationships among amylases in the yolk of fertilized eggs, and the pancreas and the serum of hens. 


\section{Materials and Methods}

Eggs were obtained from hens of the Rhode Island Red breed. Fertilized eggs were incubated in a incubator described previously ( Ikeno et al.,1991). Ten to twelve eggs were withdrawn from the incubator and used for the experiment. In some eggs, the yolk and the albumen were separated, weighed and then homogenized in $10 \mathrm{~m} l$ of saline. The pancreas of the embryo wae dissected out, weighed and the homogenized in $2 \mathrm{~m} l$ of saline. The homogenates were used for the assay of amylase activity and the separation of isoamylases by electrophoresis. Amylase activity in the yolk, albumen, pancreas and serum was assayed photometrically using blue-starch as substrate (Neo-Amylase Test, Daiichi Pure Chemical Co. Ltd.). The method is based on measurement of the released blue dye from the substrate by the enzyme reaction. One unit of amylase activity is defined as the amuont of enzyme catalyzing the change in 1.0 of absorbance at $620 \mathrm{~nm}$ per $15 \mathrm{~min}$. per $1.0 \mathrm{~g}$ of the yolk or albumen $(1.0 \mathrm{~m} l$ of the serum or $1.0 \mathrm{mg}$ of the pancreas) incubated at $37^{\circ} \mathrm{C}$.

Separation of amylases in the yolk was done by horizontal acrylamide gel electrophoresis (IKENo et al.,1992). Amylases on the gel were detected by iodine-starch reaction. The distribution of amylase in an egg was visualized by laying a frozen egg slice on CELLOGEL (Chemotron, Italy) which was in contact with blue-starch then incubated at $37^{\circ} \mathrm{C}$ until the CELLOGEL was stained a blue color by the amylase of the egg. Ten hens (Rhode Island Red breed, 35 months old) were killed by bleeding from the carotid artery. Serum was obtained from the blood and yolks from the ovaries of the hens. These yolk and pancreas were dissected out, weighed and homogenized in saline to assay the amount of amylase activity. The serum was prepared by centrifugation.

\section{Results}

Amylase activity was detected in the yolks from the ovaries of the hens. And the total amount of amylase activity was in direct proportion to the weight of the yolk

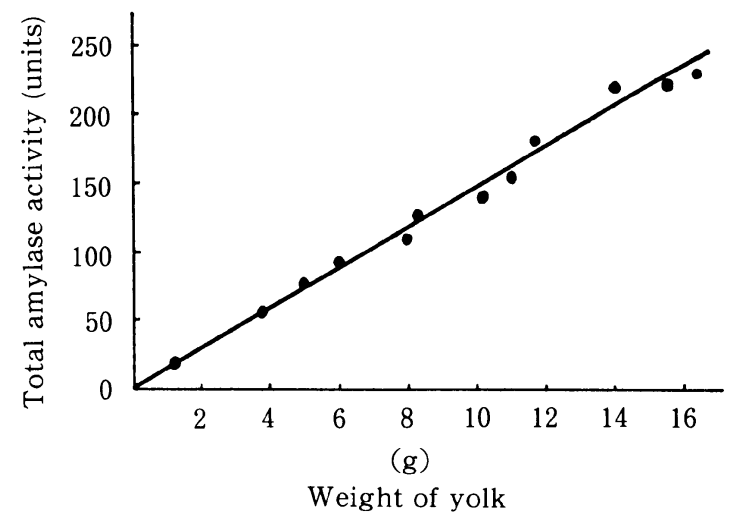

Fig. 1. Total amount of amylase activity in the yolk of the ovary. 
(Fig. 1). This result coincides with the distribution of amylase in the egg (Fig. 2). Most of the amylase activity was found in the yolk, not in the albumen, of the egg. The outside of the striped pattern was the part in contact with the albumen for the incubation period. Amylase activities were detected in a concentric configuration in both the central and peripheral portions of the yolk. Dark striped patterns show high amylase activities.

Figure 3 and Figure 4 show electrophoretic patterns of amylase in the yolk and embryo, respectively, during 16 to 22 days incubation. Each sample of the pancreas and the yolk (Fig. 3) was prepared from the same egg. Three phenotypes (A, B and $\mathrm{AB}$ ) of amylases were observed in the pancreas, and isoamylase patterns in the

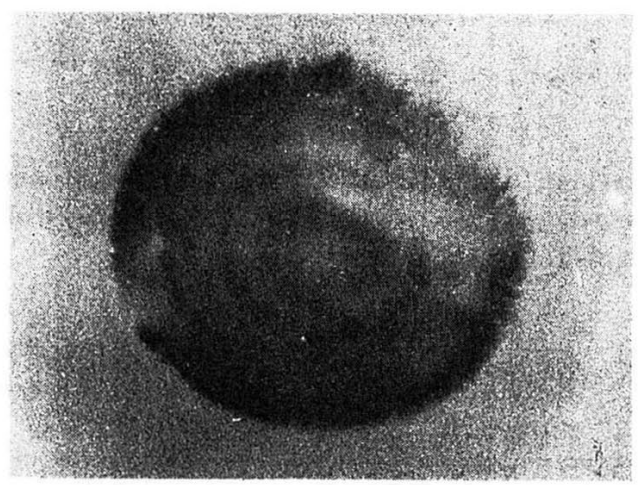

Fig. 2. Distribution of amylase activity in a cross-sectional egg.
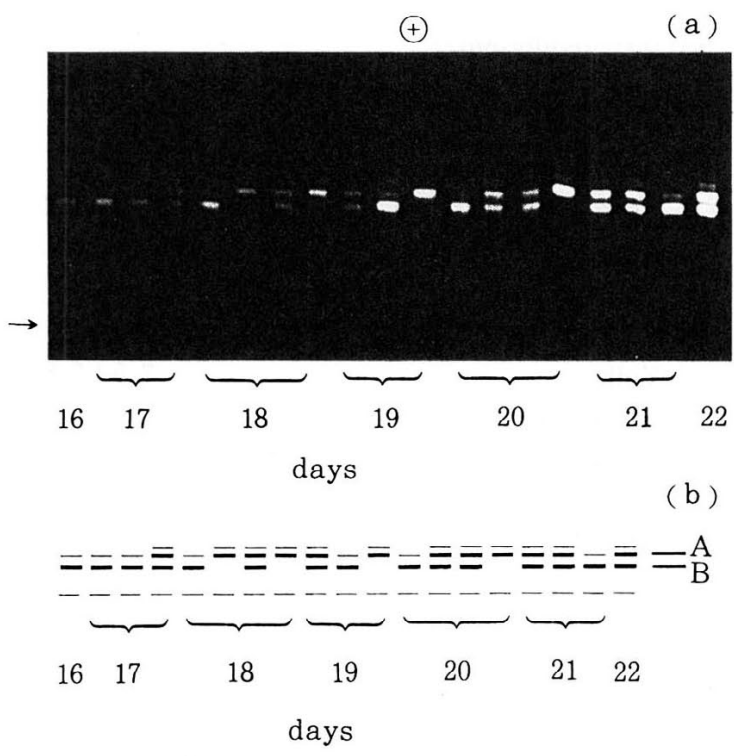

Fig. 3. Acrylamide gel electrophoretic patterns of amylases in yolks of fertile egg (16 to 22 days incubation) (a) and the diagrammatic illustration (b). 


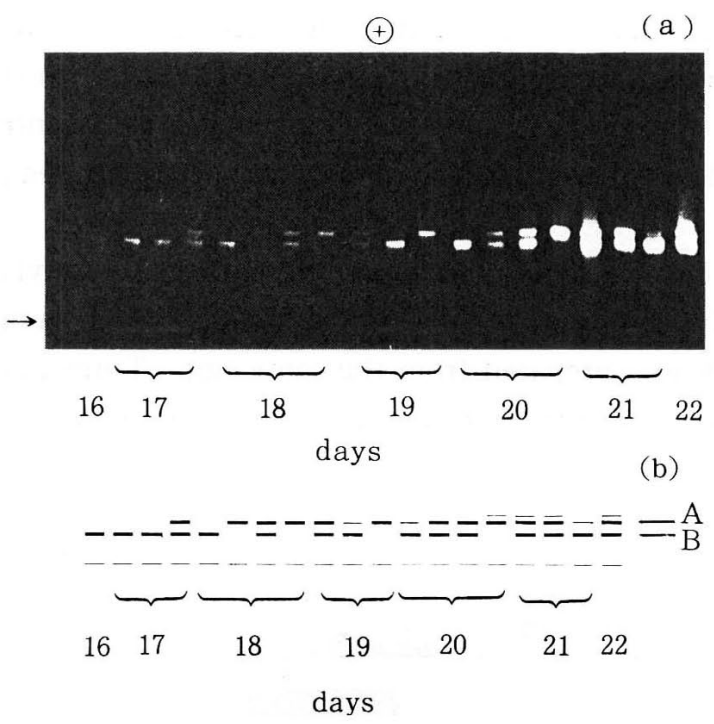

Fig. 4. Acrylamide gel electrophoretic patterns of amylases in the pancreas of chick embryos (16 to 22 days-old) (a) and the diagrammatic illustration (b).

Table 1. Amylase activity in the yolk and the albumen of the egg and in the pancreas and the serum of the hen

\begin{tabular}{cc}
\hline \hline & $\begin{array}{c}\text { Amylase activity } \\
\text { (units*) }\end{array}$ \\
\hline $\begin{array}{c}\text { Unfertilized egg } \\
\text { (1 day incubation) } \\
\text { Yolk }\end{array}$ & $8.0 \pm 0.6$ \\
Albumen & $1.0 \pm 0.1$ \\
(20 days incubation) & \\
Yolk & $11.2 \pm 1.2$ \\
Albumen & $1.1 \pm 0.1$ \\
Fertilized egg & \\
(1 day incubation) & \\
Yolk & $7.9 \pm 0.8$ \\
Albumen & $0.9 \pm 0.1$ \\
(20 days incubation) & \\
Yolk & $193.4 \pm 20.2$ \\
Albumen & $1.3 \pm 0.1$ \\
Hen $\quad$ Pancreas & \\
Serum & $291.5 \pm 18.3$ \\
\hline
\end{tabular}

${ }^{*} \mathrm{~A}$ value of 1.0 for the absorbance at $620 \mathrm{~nm}$ per $1.0 \mathrm{~g}$ of the yolk or albumen $(1.0 \mathrm{ml}$ of the serum or $1.0 \mathrm{mg}$ of the pancreas) incubated for $15 \mathrm{~min}$ at $37^{\circ} \mathrm{C}$ was defined as 1 unit. Values represent the means \pm SEM of $10-12$ samples. 
pancreas of the embryo were the same as those in the respective yolk.

Table 1 indicates the amylase activity in the yolk and albumen of eggs and in the pancreas and the serum of hens. Amylase is distributed mainly in the pancreas, although, some amylase activity was detected in the serum.

Electrophoretic patterns of amylases in the serum, in the yolk of the ovary and in the pancreas of four hens are shown in Fig. 5 (a, b). Amylase patterns of these three samples (serum, pancreas and yolk) are quite identical in same individual.

\section{Discussion}

We found amylase in the yolk of the ovary of domestic fowl. Amylase is made in layers coinciding with the formation of the yolk in the ovary. We speculated previously that the yolk of the egg was a kind of storehouse of amylase synthesized in the pancreas of the chick embryo (IKENo et al.,1991) and amylase was not synthesized in the yolk (IKENO et al.,1992). In a hen, we think that the yolk in the ovary may also be an accumulator of amylase. Amylase activity in the serum of a hen was detectable (Table 1 and Fig. 5). Amylase synthesized in the pancreas (about 292 units of amylase activity/mg pancreas) of a hen is, probably, transported into the yolk (about 8 units
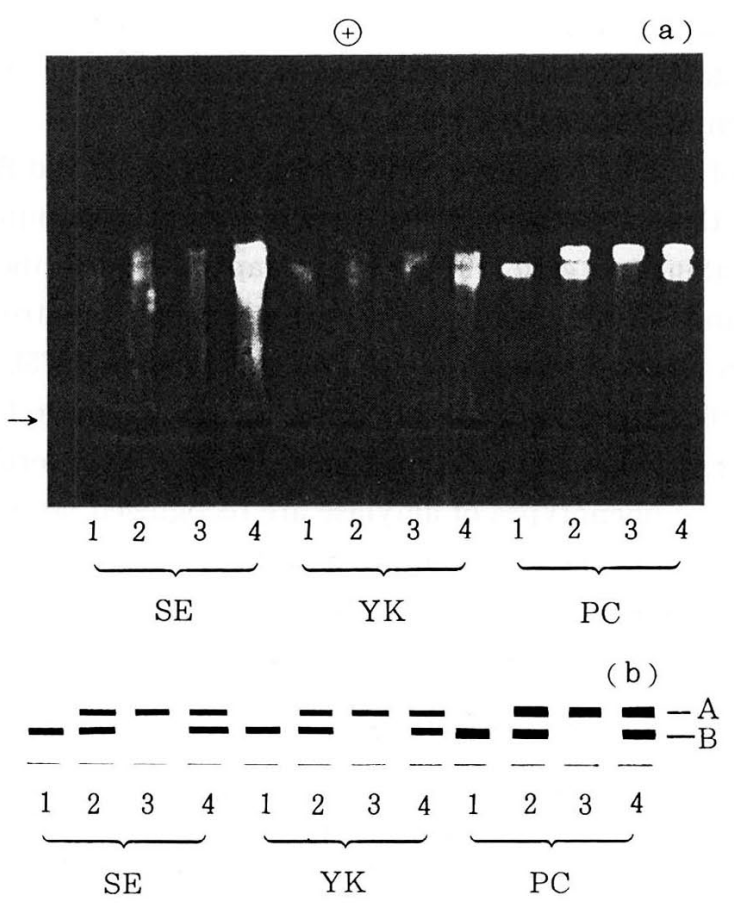

Fig. 5. Acrylamide gel electrophoretic patterns of amylases in the serum, the yolk and the pancreas of four hens $(1,2,3$, 4) (a) and the diagrammatic illustration (b). SE; serum, YK ; yolk, PC ; pancreas 
amylase activity/g yolk) via the blood (about 16 units amylase activity/m $l$ serum).

Three phenotypes of amylase in the yolks were identical to those in the pancreas and the serum in same hen (Fig. 5). These amylases are biosynthesized in a hen. One of the highest organs of amylase activity is the pancreas (Table 1). In some animals, amylases in the parotid gland or the pancreas are easily released into the blood (IKENO et al., 1982 ; SAIKATsu et al., 1989), and the released amylase is taken into the submandibular gland (IKENO et al.,1982).

Polymorphisms of egg proteins are reported using the yolk and the albumen in avian eggs. Polymorphisms of the albumen, prealbumen and transferrin are observed in the serum of a chicken. A previous paper showed that the amount of amylase activity in the yolk of fertilized egg increases markedly after 13 days of incubation (IKENO et al.,1991). Figure 3 indicated that increases in the amount of amylase activity in the yolk corresponding to the development of the chick were caused by the increase in amylase protein not by appearance of new isoamylases. There are three kinds of variations of isoamylases in the yolk of fertilized egg. We recognized three phenotypes of amylase (A, B and AB) in fertilized eggs (yolk and pancreas of embryo) and in hens (yolk, pancreas and serum). These variations depend simply upon individual variations. Variations of the yolk isoamylase were quite similar to those of the pancreatic isoamylase in respective samples (Fig. 3, 4 and 5). These results support the theory that pancreatic amylase of a chick embryo is accumulated partially in the yolk during development in fertilized egg, and in the case of a hen, pancreatic amylase of a hen is accumulated partially in the yolk during formation of the yolk in the ovary. These results suggest that some interactions exist between the embryo and the yolk during developmental periods.

In the serum of Guinea fowl, five phenotypes (A, B, C, AB and $\mathrm{BC}$ ) of amylase were distinguished and these are controlled by three autosomal codominant alleles; Amy A, AmyB and AmyC (Shiraishi et al., 1978). In the Japanese quail, there are three phenotypes ( $\mathrm{AA}, \mathrm{BB}$ and $\mathrm{AB}$ ) of serum amylase which are controlled by autosomal codominant alleles ; Amy-1A and Amy-1B (Watanabe et al., 1975). Same phenotypes of amylase were also observed in sera of some Japanese native fowl breeds (TANABE et al., 1977). But there was no report on amylase in the yolk of fertilized eggs. Figure 5 indicates that three phenotypes of amylase are recognized not only in the serum of domestic fowl but also in the yolk and the pancreas.

We hope to observe the continuous changes of isoamylase patterns in the yolk throughout the development period using a single fertilized egg.

\section{References}

Hashiguchi, T., M. YAnAgida, Y. MAedA and M. TAKetomi(1970) Genetical studies on serum amylase isozyme in fowls. Japan Journal of Genetics, $45: 341-349$.

Ikemoto, S. and H. Mukouyama (eds,) (1985) In The Comparative Hemotypology. pp 321-393., Shokabo, Japan.

IKENO, T. and K. IKeno(1991) Amylase activity increases in the yolk of a fertilized egg of domestic fowl by incubation. Poultry Science, $70: 2176-2179$.

IKENO, T., H. SAKAMOTO, K. IKENO and K. NiwA(1992) The embryo pancreas is a source of increased 
yolk amylase in the fertilized eggs of domestic fowls. Experimental Animals, $41: 19-23$.

Ineno, T., S. Hashimoto and H. Kuzuya(1982) Amylase released from the parotid gland by pilocarpine elevates the enzyme activity in the submandibular and sublingual glands of rats. Experientia, $38: 251-252$.

IKeno, T., J. NASU, S.HASHimoto and H. KuZUYA (1982) Mechanisms of increase in amylase activity in rat submandibular and sublingual glands after administration of pilocarpine. Archives of Oral Biology, 27 : 597-601.

Matsushima, Y., T. Ikeno, K. Ikeno and S. Tanaka(1990) An electrophoretic polymorphism in salivary amylases (Amy-1) of mastomys (Praomys coucha). Laboratory Animals, $24:$ 308-312.

MORAN, E.T. (1982) Starch digestion in fowl. Poultry Science, $61: 1257-1267$.

SAIKATSU, S., K. IKENo, Y. HANADA and T. IKENo (1989) Intravenous injection of caerulein or cholecystokinin increases the parotid-type and pancreatic-type amylase in the serum of rats. Japan Jounal of Oral Biology, $31: 592-596$.

SEARCY, R. L., S. HAYASHI, J.E. BERK and H. STERN (1966) Electrophoretic behavior of serum amylase in various mammalian species. Proceedings of the Society for Experimental Biology and Medicine, 122 : 1291-1295.

Shiraishi, K., S. W atanabe, T. Shibata and Y. Hirai (1978) Genetic polymorphism of serum albumin and serum amylase isozyme in the Guinea fowl. Japanese Poultry Science, 15 : 302-307.

TAnabe, Y., S. Sugiura and K. Fujioka (1977) Studies on the phylogenetic relationships of the Japanese native fowl breeds. 2. Genetic polymorphism of plasma amylases and transferrins. Japanese Poultry Science, $14: 173-178$.

Watanabe, S., S. Yoshida and T. Kawahara(1975) Serum amylase isoenzymes in the Japanese quail. Japanese Poultry Science, $12: 67-70$.

\section{ニワトリの受精卵, 卵黄, 膵臓, 血清中のアミラーゼと そのアイソザイムについて \\ 池野武行・丹羽克味 ${ }^{1}$ \\ 一宮女子短期大学 $\mathbf{T} 491$ 一宮市 \\ 1) 奥羽大学蒾学部 $\overline{\mathbf{T}} 963$ 郡山市}

ニワトリの受精卵，卵巣内卵胞，膵臓，血清を材料に してアミラーゼとそのアイソザイムを観察した。卵巣内 卵胞中のアミラーゼ活性は卵胞重量と比例して増加し層 状に分布していた。アイソアミラーゼの多型（A， B, $\mathrm{AB}$ ）は胎仔発生にともなう卵黄ならびに胎仔膵臓の他,
ニワトリの卵巣内卵胞, 膵臓, 血清中のアミラーゼにも 認められた。同一個体のそれぞれの臟器のアミラーゼの 多型は一致していた。

(家禽会誌, 32：267-273，1995） キーワード：アミラーゼ，アイソザイム，発生，卵，鶏 